\title{
The T. M. Joslin Site (41VN3) in the Sabine River Basin, Van Zandt County, Texas
}

Timothy K. Perttula

Heritage Research Center, Stephen F. Austin State University

Follow this and additional works at: https://scholarworks.sfasu.edu/ita

Part of the American Material Culture Commons, Archaeological Anthropology Commons, Environmental Studies Commons, Other American Studies Commons, Other Arts and Humanities Commons, Other History of Art, Architecture, and Archaeology Commons, and the United States History Commons

Tell us how this article helped you.

This Article is brought to you for free and open access by the Center for Regional Heritage Research at SFA ScholarWorks. It has been accepted for inclusion in Index of Texas Archaeology: Open Access Gray Literature from the Lone Star State by an authorized editor of SFA ScholarWorks. For more information, please contact cdsscholarworks@sfasu.edu. 


\section{The T. M. Joslin Site (41VN3) in the Sabine River Basin, Van Zandt County, Texas Creative Commons License \\ (c) $)(1)$ (9)}

This work is licensed under a Creative Commons Attribution-NonCommercial 4.0 International License 


\section{The T. M. Joslin Site (41VN3) in the Sabine River Basin, Van Zandt County, Texas}

Timothy K. Perttula

\section{INTRODUCTION AND SITE SETTING}

The T. M. Joslin site (41VN3) is a multi-component prehistoric site that was investigated by the University of Texas (UT) in September 1940 as Works Progress Administration (WPA) Project No. 15409 (Duffen 1940). The excavations began immediately after the UT WPA crew had finished work at the nearby Yarbrough site (41VN6) (Johnson 1962:156). The site is on a sandy knoll on Caney Creek, a northwardflowing tributary of the Sabine River in the Post Oak Savannah of East Texas (Figure 1).

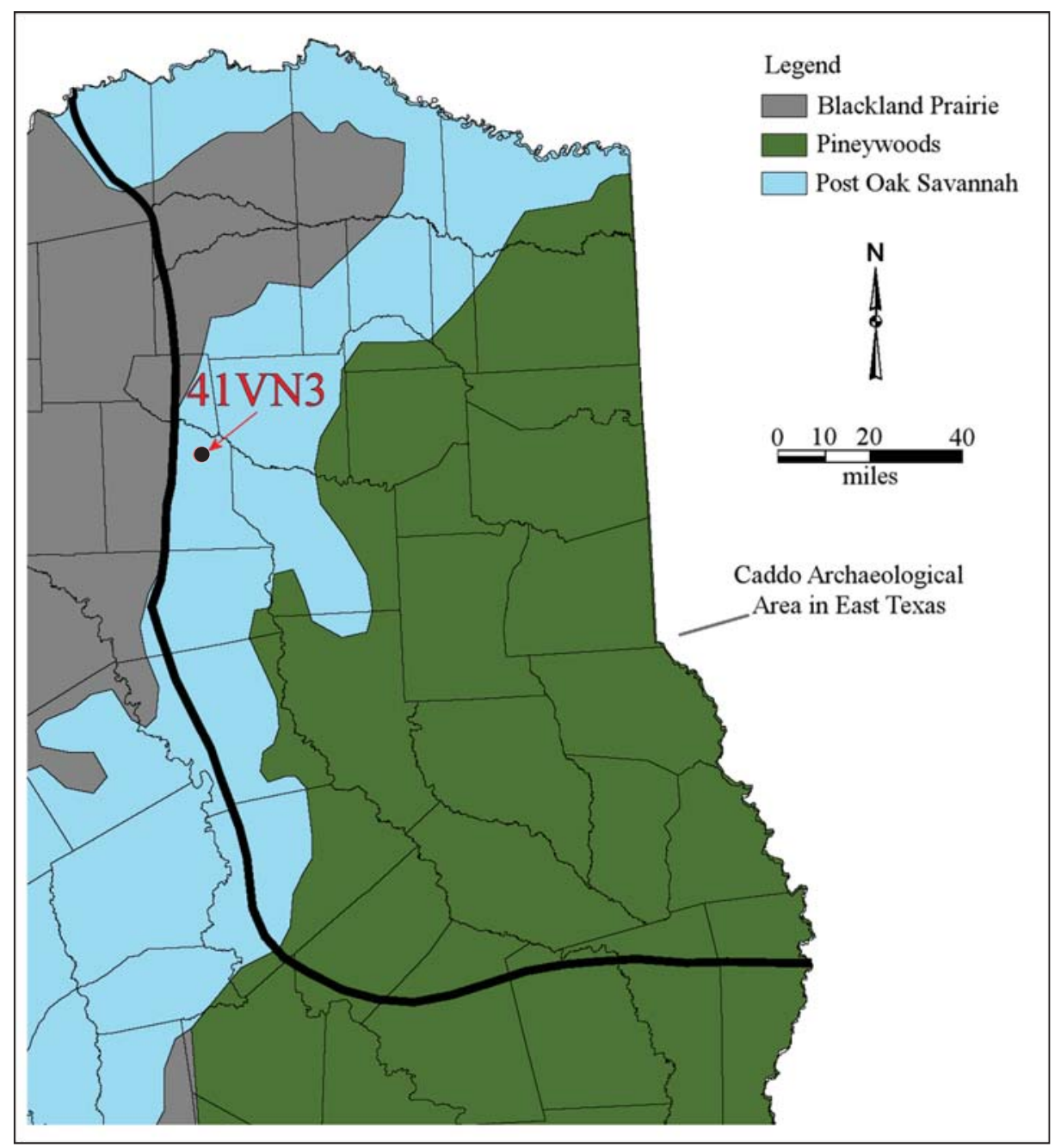

Figure 1. The location of the T. M. Joslin site (41VN3) in East Texas. 
Supervised by William A. Duffen of UT, a crew of 16 local laborers excavated a $100 \mathrm{x} 100 \mathrm{ft}$. block $(30.5 \times 30.5 \mathrm{~m})$ on the knoll between September 12-30, 1940. The local labor began their excavations with shovels at the southern end of the block, and moved north at the completion of each $10 \mathrm{ft}$. row, working from the completed vertical face of the previous row (Duffen 1940). The archaeological deposits were described by Duffen as a shallow midden overlying a red clay subsoil; the subsoil was reached between 1.0-1.3 ft. bs (ca. 30-41 cm bs) and the upper plow zone extended from $0-13 \mathrm{~cm}$ bs. No cultural features were identified in the WPA excavations, but a very large Canton Incised jar was reconstructed from a large sherd concentration encountered at ca. $25 \mathrm{~cm}$ bs (see below). A. T. Jackson, who had first visited the site in the Spring of 1930, before he began to work at UT, had discovered in a "test hole" portions of a large ceramic bowl (36 cm in diameter) and a large water bottle (Jackson 1930), presumably from a Caddo burial feature, but he did not further explore the feature. About $15 \mathrm{~m}$ away he found remnants of a dog burial. It is not known where these finds were in relationship to the WPA excavations.

\section{ARTIFACT ASSEMBLAGE}

The artifact assemblage from the excavations at the T. M. Joslin site include both ceramic sherds $(n=625)$, a reconstructed ceramic vessel, and chipped stone tools $(n=73)$. Most of the chipped stone tools are dart points $(n=43)$ and discarded bifaces $(n=17)$ representing several stages of tool manufacture.

\section{Ceramic Sherds}

The ancestral Caddo ceramic assemblage from the T. M. Joslin site includes sherds from plain ware, fine ware, and utility ware vessels (Table 1). Utility ware sherds outnumber fine wares by a ratio of 3.6:1, and almost 70 percent of the rims in the assemblage are from utility wares. The plain to decorated sherd ratio is 6.9:1.

Table 1. Ceramic assemblage from the T. M. Joslin site.

\begin{tabular}{lrrrr}
\hline Ware & Rim & Body & Base & N \\
\hline Plain & 8 & 514 & 24 & 546 \\
Fine & 5 & 12 & - & 17 \\
Utility & 29 & 33 & - & 62 \\
\hline Totals & 42 & 559 & 24 & 625 \\
\hline
\end{tabular}

The majority of the Caddo ceramic sherds in the assemblage are tempered with grog or crushed sherds (Table 2): 87.3 percent. The remainder are tempered with bone (12.7 percent). The proportion of bone temper in the vessel sherds from the T. M. Joslin site is quite comparable to the assemblage from Area A at the nearby Yarbrough site - at 14.7 percent (see Johnson 1962) - but much less than has been documented in the Area B ceramic assemblage at the Yarbrough site: 34 percent.

Table 2. Temper in the decorated sherds from the T. M. Joslin site.

\begin{tabular}{lccc}
\hline Ware & Grog & Bone & N \\
\hline Fine & 14 & 3 & 17 \\
Utility & 55 & 7 & 62 \\
\hline Totals & 69 & 10 & 79 \\
\hline
\end{tabular}


The 79 decorated sherds from the site include both utility wares (78 percent) and fine wares (Table 3); the ratio of utility ware rim sherds to fine ware rims is 5.8:1. Among the utility wares, more than 80 percent are from jars with incised decorative elements around the rim, primarily Canton Incised jars (see Suhm and Jelks 1962:Plate 12). Most of the incised rim and body sherds are from Canton Incised jars with crosshatched lines (Figure 2a-d), as well as diagonal incised lines, diagonal opposed incised lines (Figure 2e-f), horizontal and diagonal incised lines (Figure 2g), and hatched incised triangles (Figure 2h).

Table 3. Decorative elements in utility ware and fine ware sherds from the T. M. Joslin site.

\begin{tabular}{llll}
\hline Decorative element & Rim & Body & N
\end{tabular}

Utility Ware

\section{Appliqued}

straight appliqued ridge

1

\section{Incised}

cross-hatched lines

diagonal lines, L-R

16

10

26

diagonal lines, R-L

$-$

$4^{*}$

diagonal opposed lines

hatched triangle

horizontal lines

horizontal and cross-hatched lines

horizontal and diagonal lines

parallel lines

straight line

vertical lines

\section{Incised-Appliqued}

straight appliqued ridge and opposed

incised lines

\section{Incised-Punctated}

diagonal incised panels filled with tool punctates

diagonal opposed incised triangles filled with tool punctates

\section{Punctated}

fingernail punctated rows 
Table 3. Decorative elements in utility ware and fine ware sherds from the T. M. Joslin site, cont.

\begin{tabular}{lccc}
\hline Decorative element & Rim & Body & N \\
\hline Fine Ware & & & \\
Engraved & & - & 1 \\
cross-hatched lines & 1 & 2 & 2 \\
curvilinear lines & - & 1 & 1 \\
diagonal lines, L-R & - & - & 1 \\
diagonal lines, R-L & 1 & - & 1 \\
diagonal lines, R-L and triangle el. & 1 ** & 1 & 1 \\
hatched triangle & 1 & & 2 \\
parallel lines & - & 2 & 7 \\
Red-Slipped & & 6 & 17 \\
ext. red-slipped & - & 12 & 79 \\
int./ext. red-slipped & $1+$ & 45 & \\
Subtotal, fine wares & 5 & & \\
\hline Totals & 34 & & \\
\hline
\end{tabular}

*two rims are also lip notched

**lip notched, red-slipped, and interior surface engraved decoration

+scalloped lip

$\mathrm{L}-\mathrm{R}=$ left to right; incised or engraved lines begin at the left at the top of the rim and end at the right at the bottom of the rim;

$\mathrm{R}-\mathrm{L}=$ right to left: incised or engraved lines begin at the right at the top of the rim and end at the left at the bottom of the rim

Appliqued sherds comprise 1.6 percent of the utility wares from the T. M. Joslin site (see Table 3); there were no sherds with appliqued decorative elements from the Yarbrough site (see Johnson 1962:202-206, 226-230). One incised-appliqued body sherd of unidentified type has a straight appliqued ridge and opposed incised lines (Figure 3a).

The incised-punctated rim and body sherds represent 6.4 percent of the utility wares from the site (see Table 3). These are from Canton Incised jars that have diagonal opposed incised triangles filled with tool punctates (see Figure 3b, d) as well as diagonal incised panels with tool punctates in the panels (see Figure 3c).

Two rim sherds are lip notched (see Table 3). They probably represent a variety of Sanders Plain (see Suhm and Jelks 1962:139). The notching of the lips of vessels at the sole rim decoration is an apparently distinctive decorative method in a number of different Caddo communities of different ages in East Texas. The earliest assemblages, dating from ca. A.D. 900-1300, with lip notched vessels occur in the upper Red, upper and middle Sabine, and in the Angelina River basins (Perttula 2015:Figure 9); this includes one lip notched Sanders Plain bowl from the nearby Yarbrough site (Johnson 1962:Figure 23i). Middle Caddo communities (ca. A.D. 1300-1400) in these same parts of East Texas also had lip notched vessels.

Only 4.8 percent of the utility ware sherds have punctated decorative elements (see Table 3 ). These sherds either have rows of fingernail or tool punctates.

More than 52 percent of the fine ware sherds from the T M. Joslin site are from red-slipped Sanders Plain vessels, bowls and carinated bowls (see Table 3); one rim has a scalloped lip (see Suhm and Jelks 1962:139). As redefined by Brown (1996:401-403 and Figures 2-191, 2-34g, 2-37a-1, 2-38d, 2-39d, k, n-q, and 2-42b), 


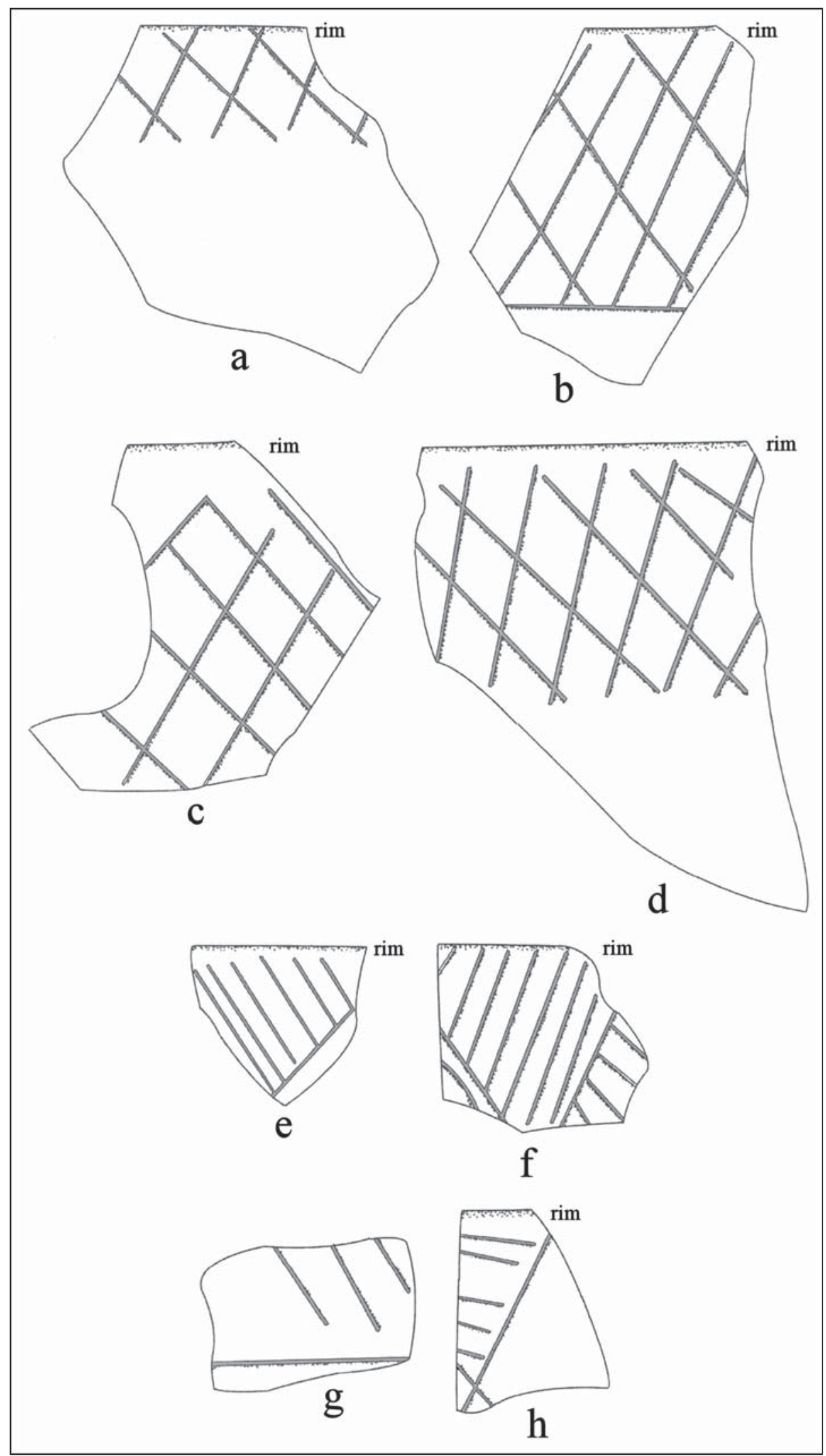

Figure 2. Decorative elements on incised sherds from the T. M. Joslin site: a-d, cross-hatched lines; e-f, diagonal opposed lines; g, horizontal and diagonal lines; $\mathrm{h}$, hatched incised triangle element. 


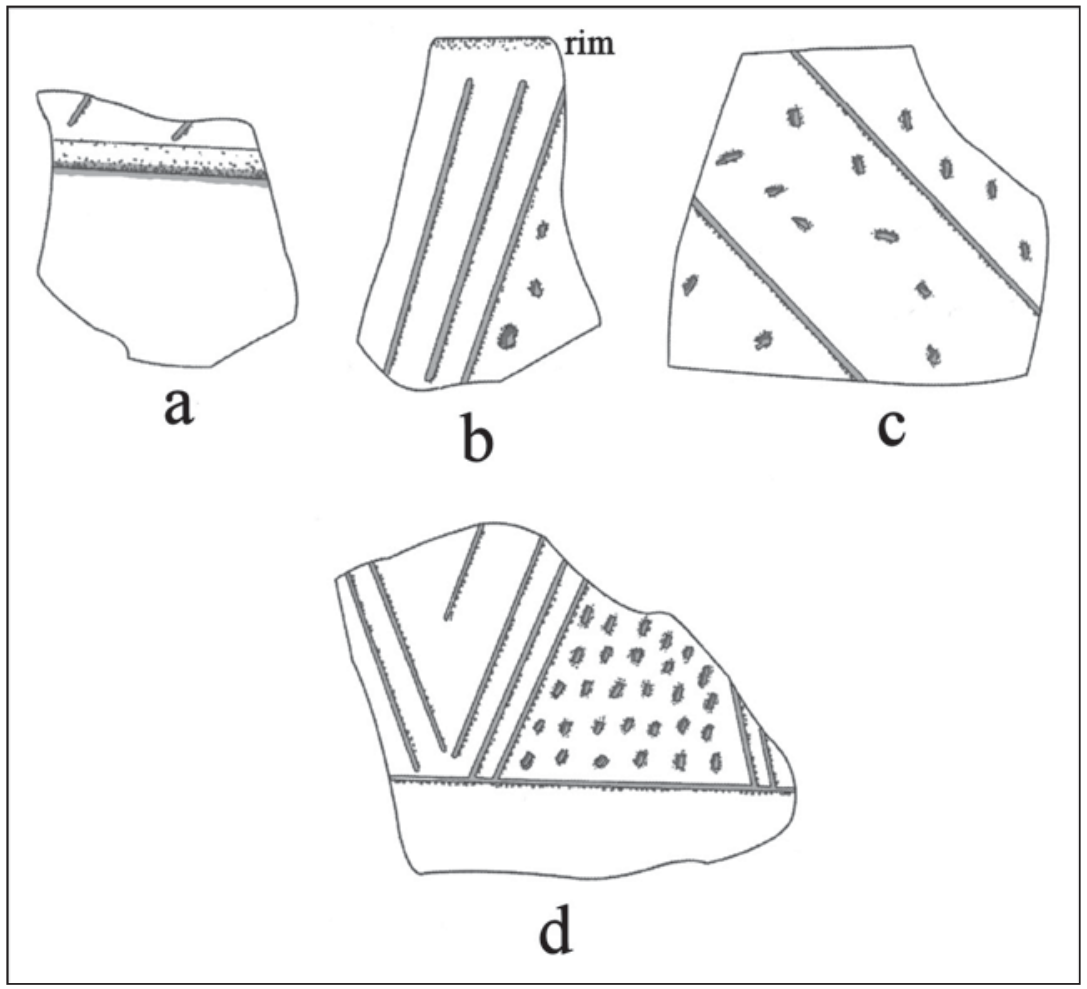

Figure 3. Decorative elements on incised-appliqued and incised-punctated sherds from the T. M. Joslin site: a, incised-appliqued body sherd; b-d, incised-punctated rim and body sherds.

Sanders Plain is a grog-tempered, slipped, and undecorated type found widely across the Caddo area. Vessel forms include bowls, carinated bowls, and narrow and wide-mouthed bottles. Red-slipped fine wares are a common part of ancestral Caddo ceramic assemblages in several parts of East Texas, most notably in sites in the middle Red River, the Big Cypress Creek basin, the upper Sulphur and Sabine River basins, and the middle Sabine River basin (Perttula 2015:Figure 3).

The engraved sherds with cross-hatched, diagonal, and hatched triangle elements (Figure 4b; see Table 3) are from Sanders Engraved vessels (see Suhm and Jelks 1962:Plate 69). The most distinctive fine ware rim sherd in the T. M. Joslin ceramic assemblage is likely from a Spoonbill Engraved bowl (although it does not have an interior thickened rim) that has interior and exterior red-slipped surfaces, a notched lip, and an engraved decoration on the interior vessel surface (Figure 4a): diagonal lines and a row of open triangles. Spoonbill Engraved was defined by Perttula et al. (2009) on the basis of several engraved bowls recovered from Middle Caddo period sites in the upper Sabine River basin. These vessels had interior thickened rims with upper and lower sets of hatched (3-4 hatched lines) engraved triangles on the interior vessel surface.

\section{Ceramic Vessel}

A very large Canton Incised jar from the T. M. Joslin site has been reconstructed from 118 sherds found at ca. $25 \mathrm{~cm}$ bs in the block excavations. The grog-tempered jar stands $48.7 \mathrm{~cm}$ in height and has a $41.6 \mathrm{~cm}$ orifice diameter (Figure 5). The estimated volume of the jar is approximately 26 liters.

The jar is decorated around the rim with a series of diagonal incised lines that are pitched in alternate directions, forming incised triangles. The incised triangles are filled with rows of tool punctations (see Figure 5; see also Suhm and Jelks 1962:Plate 12h). 


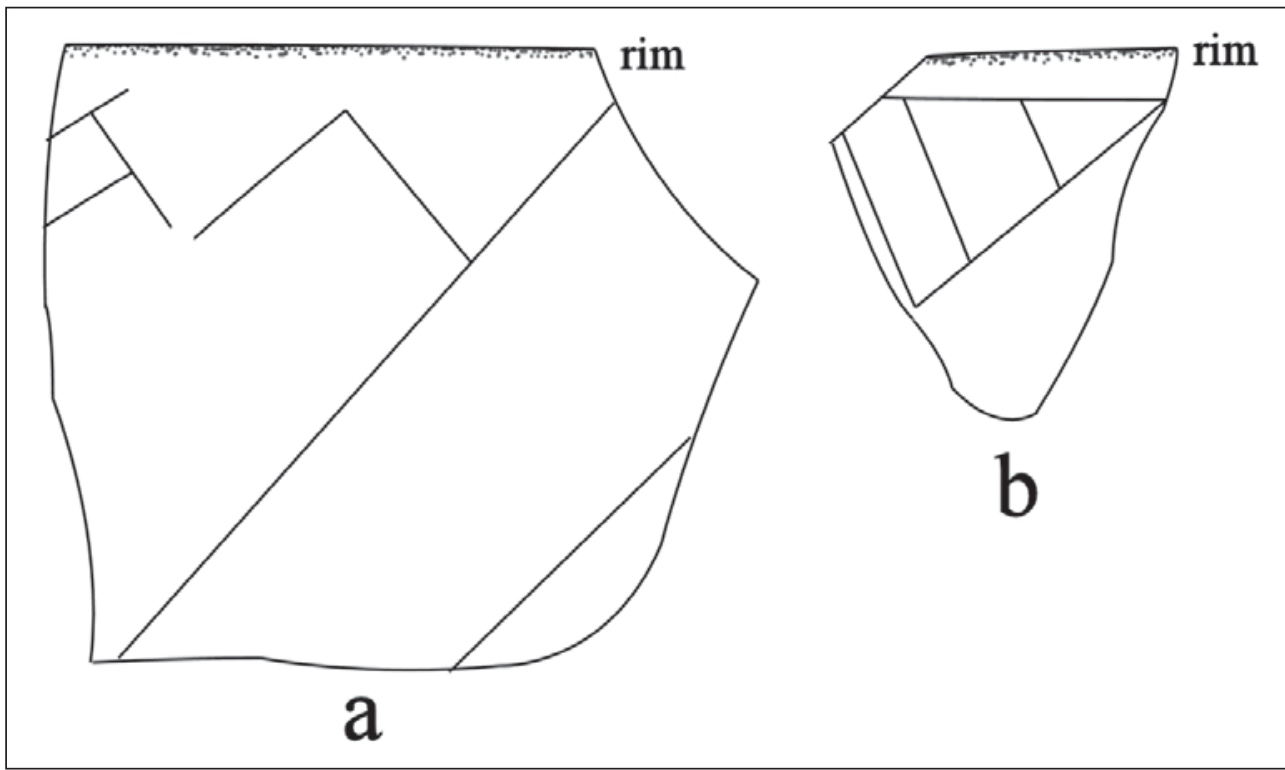

Figure 4. Decorative elements on engraved sherds from the T. M. Joslin site: b, hatched triangle element; a, red-slipped rim sherd with diagonal engraved lines and triangle elements.

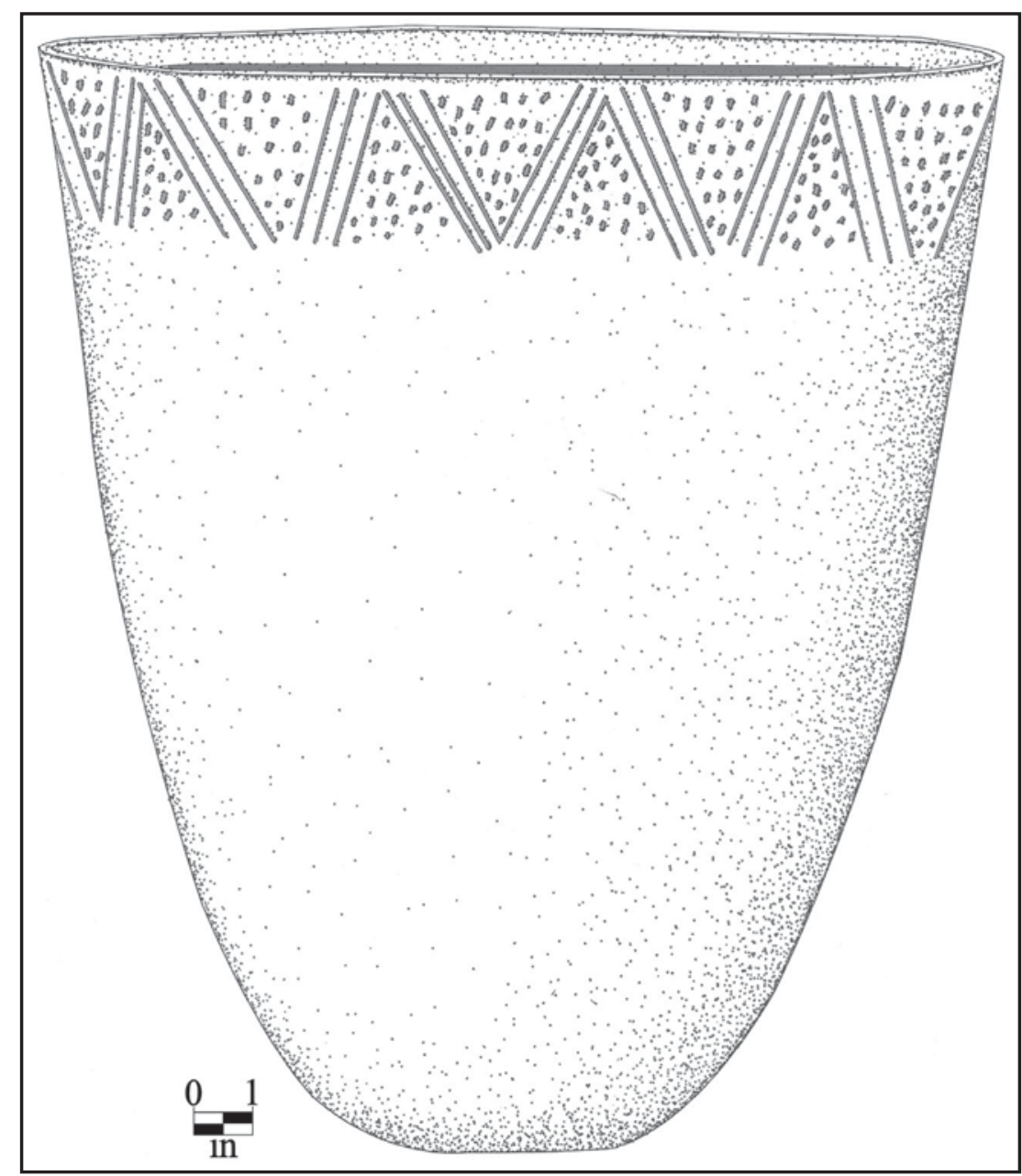

Figure 5. Canton Incised jar from the T. M. Joslin site. 


\section{Chipped Stone Tools}

A number of the stone tools from the T. M. Joslin site are made from a very coarse gray to grayish-red quartzite; there are known local sources of this raw material on the Sabine River (see Malone 1972). There are also other local raw materials, including fine-grained Ogallala quartzite and petrified wood raw materials, and there are also several kinds of non-local cherts (Table 4). About 22 percent of the chipped stone tools are of the distinctive coarse-grained quartzites (and ferruginous sandstone), especially broken bifaces and manufacturing failures, gouges, and Gary dart points. Fine-grained (and mainly heat-treated) quartzite comprises 47 percent of the tools - including primarily bifaces and dart points - and local petrified wood another 18 percent (primarily gouges; Johnson [1962:189 and Figure 10r-t] labeled these Mineola end scrapers). Chipped stone tools made of non-local cherts and novaculite (gray chert, brownish-gray chert, grayish-brown chert, yellowish-gray chert, and white novaculite) represent 13.7 percent of the tool assemblage (Table 4), and are most common among the scrapers, the one flake tool, and the one bifacial adze.

Table 4. Chipped stone tools in the T. M. Joslin assemblage.

\begin{tabular}{|c|c|c|c|c|c|}
\hline Tool type & CQTZ & fgQTZ & PW & non-local chert & $\mathrm{N}$ \\
\hline end-side scraper & - & - & - & 1 & 1 \\
\hline side scraper & - & - & - & 1 & 1 \\
\hline flake tool, unilateral & - & - & - & 1 & 1 \\
\hline drill & - & 1 & - & - & 1 \\
\hline adze & - & - & - & 1 & 1 \\
\hline gouge & $2+$ & - & 5 & - & 7 \\
\hline early stage biface & 4 & 1 & 1 & - & 6 \\
\hline mid-stage biface & 1 & 3 & - & - & 4 \\
\hline final stage biface & 2 & 3 & 1 & 1 & 7 \\
\hline Alba arrow point & - & - & 1 & - & 1 \\
\hline dart point blade fragments & 1 & 1 & - & - & 2 \\
\hline Lanceolate point & - & - & - & 1 & 1 \\
\hline Gary dart point* & 6 & 15 & 2 & 2 & 25 \\
\hline Gary preform & - & 3 & - & - & 3 \\
\hline Godley dart point & - & 1 & - & - & 1 \\
\hline Kent dart point & - & 2 & 1 & $1 * *$ & 4 \\
\hline Morrill dart point & - & 3 & - & 1 & 4 \\
\hline Pontchartrain dart point & - & - & 1 & - & 1 \\
\hline Trinity dart point & - & 1 & - & - & 1 \\
\hline Wells dart point & - & - & 1 & - & 1 \\
\hline Totals & 16 & 34 & 13 & 10 & 73 \\
\hline
\end{tabular}

$\mathrm{CQTZ}=$ coarse-grained quartzite; fgQTZ=fine-grained quartzite; $\mathrm{PW}=$ petrified wood

*does not include one point made from hematite

**made from novaculite

+includes one gouge made from ferruginous sandstone 
One of the dart points from the T. M. Joslin site is a Late Paleoindian period (ca. 10,000 years B.P.) lanceolate form made from a non-local grayish-brown chert (see Table 4). The point has stem grinding, no fluting scars on the base, and a heavily resharpened blade. There are several Late Archaic (ca. 5000-2500 years B.P.) dart points from the site $(n=7)$, primarily of the Morrill type. They are made from fine-grained quartzite (57 percent) and petrified wood (29 percent), and one Morrill point is made from a non-local gray chert.

Including three preforms, the Woodland period (ca. 2500-1250 years B.P.) dart points-Gary, Godley, and Kent types - represent more than 80 percent $(n=33)$ of the typologically identifiable dart points from the T. M. Joslin site (see Table 4); most of these are contracting stem dart points. The stem widths of the Gary points range from 10.9-17.5 mm, with a mean stem width of $13.9 \mathrm{~mm}$. These Woodland points are mostly made from fine-grained quartzite (64 percent), but there is also a significant use of the coarse-grained quartzite (18 percent); petrified wood ( 9 percent); and non-local cherts and novaculite ( 9 percent).

The one arrow point in the assemblage is a petrified wood Alba point (see Table 4). It likely is associated with the ca. A.D. 1200-1400 ancestral Caddo occupation at the T. M. Joslin site.

\section{SUMMARY AND CONCLUSIONS}

The T. M. Joslin site (41VN3) is a prehistoric archaeological site on a tributary stream in the upper Sabine River basin in the Post Oak Savannah of East Texas. First cursorily investigated by A. T. Jackson in 1930, in 1940 the University of Texas completed the excavation of a ca. 30.5 x 30.5 m block excavation at the site under the auspices of the Works Progress Administration; William A. Duffen led the field work. The archaeological deposits were shallow (ca. 0-40 cm bs), and no features were identified by the crew except for one reconstructable ceramic jar; Jackson's 1930 investigations encountered an ancestral Caddo burial as well as a dog burial.

The archaeological material culture remains recovered in the investigations document the long-term and periodic use of the T. M. Joslin site by aboriginal peoples. A variety of chipped stone projectile points recovered from the site indicate that it was occupied initially during the Late Paleoindian period, then more substantially during the Late Archaic and Woodland periods. The principal archaeological component at the T. M. Joslin site was during the Middle Caddo period, from ca. A.D. 1200-1400, when it was likely a settlement occupied for several years by a group of Caddo peoples. The component's ceramic assemblage is dominated by sherds from grog-tempered plain, utility, and fine ware vessels, including Canton Incised jars, Sanders Plain bowls and carinated bowls, Sanders Engraved bowls and carinated bowls, and a Spoonbill Engraved bowl. The ancestral Caddo ceramic assemblage here shares both technological and stylistic characteristics with other Middle Caddo period sites in the upper Sabine River basin (see Bruseth and Perttula 1981; Johnson 1962; Perttula and Cruse 1997; Perttula et al. 1993, 2009).

\section{ACKNOWLEDGMENTS}

Thanks to Jonathan Jarvis for facilitating the study of the collections and records from the T. M. Joslin site at the Texas Archeological Research Laboratory, The University of Texas at Austin. Lance Trask provided the figures for this article. 


\section{REFERENCES CITED}

Brown, J. A.

1996 The Spiro Ceremonial Center. The Archaeology of Arkansas Valley Caddoan Culture in Eastern Oklahoma. 2 Vols. Memoir No. 29. Museum of Anthropology, University of Michigan, Ann Arbor.

Bruseth, J. E. and T. K. Perttula

1981 Prehistoric Settlement Patterns at Lake Fork Reservoir. Texas Antiquities Permit Series, Report No. 2. Texas Antiquities Committee and Southern Methodist University, Austin and Dallas.

Duffen, W. A.

1940 Site No. 28A5-3, T. M. Joslin Place, 2 miles northwest of Grand Saline, Van Zandt County, Texas. MS on file, Texas Archeological Research Laboratory, The University of Texas at Austin.

Jackson, A. T.

1930 Artifacts in Vicinity of Speer Site. MS on file, Texas Archeological Research Laboratory, The University of Texas at Austin.

Johnson, L., Jr.

1962 The Yarbrough and Miller Sites of Northeastern Texas, with a Preliminary Definition of the LaHarpe Aspect. Bulletin of the Texas Archeological Society 32:141-284.

Malone, J. M.

1972 Archaeological Reconnaissance at Proposed Mineola Reservoir. Archeological Survey Report No. 10. Texas Historical Survey Committee, Austin.

Perttula, T. K.

2015 East Texas Caddo Ceramic Sherd Database. Journal of Northeast Texas Archaeology 51, in press.

Perttula, T. K. and J. B. Cruse

1997 The Caddoan Archaeology of the Sabine River during the Middle Caddoan Period. Journal of Northeast Texas Archaeology 9:30-37.

Perttula, T. K., B. D. Skiles, and B. C. Yates

1993 The Carlisle Site (41WD46), a Middle Caddoan Occupation on the Sabine River, Wood County, Texas. Notes on Northeast Texas Archaeology 1:34-62.

Perttula, T. K., M. Walters, S. Marceaux, and B. Nelson

2009 Caddo Pottery Vessels and Pipes from Sites in the Middle and Upper Sabine and Upper Neches River Basins, Smith and Wood Counties, Texas. Special Publication No. 7. Friends of Northeast Texas Archaeology, Pittsburg and Austin. 